\title{
Study Bible on the Old Testament
}

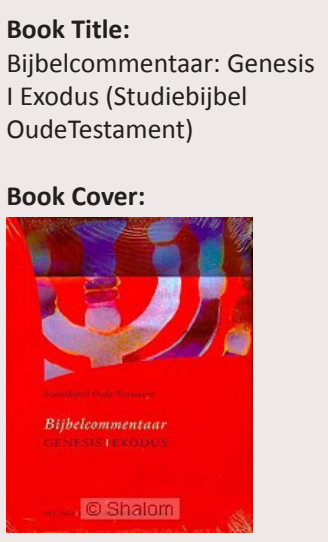

Author:

M.J. Paul, G. van den Brink \& J.C. Bette

ISBN:

9789077651018

Publisher:

Centrum voor

Bijbelonderzoek,

Veenendaal, 2004, p. 1026 ,

$€ 65 *$

*Book price at time of Review

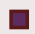

Review Title:

Study Bible on the Old

Testament

Reviewer:

Pieter M. Venter

\section{Affiliation:}

${ }^{1}$ Department of Old

Testament Studies,

University of Pretoria,

South Africa

Email:

pm.venter@up.ac.za

Postal address:

PO Box 914-1530, Wingate

Park 0153, South Africa

C 2011. The Authors.

Licensee: AOSIS

OpenJournals. This work

is licensed under the

Creative Commons

Attribution License.
This is the first in the Studiebijbel Oude Testament [Study Bible on the Old Testament] series, the companion to the Studiebijbel Nieuwe Testament. The series is unique in its structure, especially with regard to lay-out and presentation. The Hebrew text, as it appears in the Biblia Hebraica Stuttgartensia appears on the left pages. The applicable number from Strong's Exhaustive Concordance (1890) is printed above each separate Hebrew word. A transliteration of the particular Hebrew word and an interlinear Dutch translation of this word appear below the word. On the same page, in a column on the right hand side, the difference in translation between five different Dutch Bible translations is indicated, ranging from the 1977 edition of the Statenvertaling to the latest, De Nieuwe Bijbelvertaling of 2004.

On the page on the right, a verse by verse commentary, as well as extensive footnotes to the text appears. Diagrams and maps are also included and these appear mainly on the page on the right.

The Genesis and Exodus commentary contains introductions to both Bible books, dealing with issues such as the book's place in the Christian canon, research done on the book, the book's structure, its probable author and its theological message. On pages 963-1029, excursen [excursus] and an overview on literature used are printed. These excursen deal with topics such as chronology, other literary traditions from the Ancient Near East, covenant making, Sodom-Gomorrah-archaeology, history of religion, the meaning of blessings, family structure, and Israel in Egypt.

It is in the appendix in particular that the approach the publisher, Centrum voor Bijbelonderzoek [Centre for Bible Research] follows becomes clear. It is an orthodox or conservative stance that takes note of critical investigation but tends to defend the more conservative viewpoints. The first excursus serves as an example. Dealing with the chronological problem of creation and deluge, it is accepted that the genealogies in the Bible are incomplete and that some names are omitted. It is therefore not possible to exactly determine from these the time that had elapsed between creation and deluge. Whilst orthodox exegetes reject the evolution theory, it is still their aim to reconstruct the history presented in Genesis as accurately as possible. According to their calculations the deluge took place ca. $10000 \mathrm{BCE}$ and the creation, a few thousand years earlier.

This approach focuses on the Hebrew text. This text is not only compared to the Qumran Scrolls and Samaritan Pentateuch, as well as to translations similar to the Septuagint, but is thoroughly analysed for its structure and literary type. Genesis is shown to have a toledot [human generation] structure characterised by parallel and chiastic structures used throughout the book.

When it comes to the book's background, preference is given to historical reconstruction, using mainly archaeological data. An example of the way in which historical truth is linked to authority can be found in the conclusion on page 21. The commentary holds the view that Genesis fits neatly into the context of the third and second millennium BCE. Although its historicity cannot be proven, it was definitely not written during the monarchic time or the Babylonian exile. This means that the commentary acknowledges that no specific time can be indicated, but the basic opinion is still that it was written during the times it refers to. As a 'first hand' report it is therefore authoritative, and because of this historical credibility, it is the authoritative word of God. Translated, the commentary says: 'whoever the author was and whenever the book was created, it is still the authoritative word of God, according to 2 Tim 3:16'. Of course, this excludes the monarchical and exilic time that will make it historically unreliable and, therefore, not the authoritative word of God!

Another characteristic of the commentary is the belief that Old and New Testament belong together as the word of God. Scripture shows a unity. In the commentary the ideas and terms in the GenesisExodus texts found elsewhere in the Old Testament and the Bible are indicated, and are used as hermeneutic context to elucidate the specific passage. In the background the idea exists that all of

How to cite this book review: Venter, P.M., 2011, 'Study Bible on the Old Testament', HTS Teologiese Studies/Theological Studies 67(3), Art. \#1142, 2 pages. http://dx.doi.org/10.4102/hts.v67i3.1142 
the Bible is the revelation of God and is therefore organically related. In Bette's foreword he spells out the policy followed in the commentary:

It is the publisher's intention to give clear exposition of the Bible to enable readers to understand that this book leads us to the Lord Jesus Christ who said that Scriptures testify about Him (Jn 5:39).
This commentary can be recommended for its unique concept of presentation of the Hebrew text and for its thorough analysis of the structure of the text. As far as its exegesis, based on the approach indicated earlier, is concerned, there will be a difference of opinion. There will be those who would welcome and use the commentary with great joy, whilst others will approach it with skepticism. 